Milan 기준을 넘는 간세포암종에서 방사선색전술, 간동맥 화학요법 및 정위체부방사선치료를 통한 Down-staging 후 성공적인 생체간이식을 시행한 1 예

김영진 ${ }^{1} \cdot$ 정연승 $^{2} \cdot$ 김범경 ${ }^{1,3} \cdot$ 성진실 $^{3,4} \cdot$ 김도영 $^{1,3}$

연세대학교 의과대학 ${ }^{1}$ 내과학교실, ${ }^{2}$ 병리학교실, ${ }^{3}$ 세브란스병원 간센터, ${ }^{4}$ 연세대학교 의과대학 방사선종양학교실

\title{
A Case of Successful Living Donor Liver Transplantation after Down- staging of Hepatocellular Carcinoma with the Beyond Milan Criteria by Radioembolization, Hepatic Arterial Infusion Chemotherapy, and Stereotactic Body Radiation Therapy
}

\author{
Yeong Jin Kim', Yeon Seung Chung'2 , Beom Kyung Kim, ${ }^{1,3}$ Jin Sil Sung ${ }^{3,4}$, Do Young Kim ${ }^{1,3}$ \\ Departments of ${ }^{1}$ Internal Medicine, ${ }^{2}$ Pathology, Yonsei University College of Medicine, ${ }^{3}$ Yonsei Liver Center, Severance Hospital, \\ ${ }^{4}$ Department of Radiation Oncology, Yonsei University College of Medicine, Seoul, Korea
}

Received Jul. 16, 2017

Revised Aug. 22, 2017

Accepted Aug. 25, 2017
Liver transplantation for patients with hepatocellular carcinoma (HCC) within the Milan criteria generally yields a 4 -year overall survival rate of $75 \%$ and 4 -year recurrence free survival rate of $83 \%$. But, many HCC patients present with the disease beyond the Milan criteria. On the other hands, the overall survival of patients with advanced HCC with portal vein invasion is very poor. We report a case of successful living donor liver transplantation for advanced HCC with portal vein invasion by down-staging through radioembolization, hepatic arterial infusion chemotherapy, and stereotactic body radiation therapy. (J Liver Cancer 2017;17:182-185)

Keywords: Liver neoplasms; Liver transplantation

\section{서 론}

간이식은 간세포암종 및 기저 간질환까지 치료할 수 있는 가장 이상적인 치료법이다. 초기에는 간이식 후 5년 생존율 이 $40 \%$ 미만이었지만 ${ }^{1}$ 간외전이와 혈관침범이 없는 $5 \mathrm{~cm}$ 이 하 단일 종양 혹은 각 종양의 크기가 $3 \mathrm{~cm}$ 이하인 3 개 이하 의 다발성 간세포암종에서 간이식을 진행하는 Milan 기준

\section{Corresponding author: Do Young Kim}

Department of Internal Medicine, Yonsei University College of Medicine, 50-1 Yonsei-ro, Seodaemun-gu, Seoul 03722, Korea

Tel. +82-2-2228-1992, Fax. +82-2-2227-7877

E-mail; dyk1025@yuhs.ac

http://orcid.org/0000-0002-8327-3439
을 적용함으로써 간이식 후 4년 생존율 $75 \%$, 무병 생존율 $83 \%$ 를 달성하였다. ${ }^{2}$ 그러나, 실제로 많은 환자들이 Milan 기 준을 넘는 간세포암종을 가지고 있으며 진행된 간세포암종 에서는 sorafenib 투약을 하더라도 중간 생존기간이 6.5개월 로 불량하다. ${ }^{3}$ 이러한 진행성 간세포암종 환자에서는 downstaging 후 간이식을 진행하는 것이 완치를 위한 한 가지 방 법일 수 있으며, 기존에 알려진 방법의 단독치료 혹은 병용 치료를 통해 down-staging을 노려볼 수 있다. 기존 메타분석 을 통하여 down-staging의 성공률은 $50 \%$ 미만으로 알려져 있으며 특히 문맥의 종양 혈전을 동반한 경우에 더 낮았다. 본 저자들은 크기가 크고 간문맥 침윤이 동반되어 Milan 기 준을 넘는 진행된 간세포암종에서 방사선색전술, 정위체부 방사선치료 및 간동맥 화학주입술을 통한 down-staging 후 
성공적인 생체간이식을 시행한 증례를 보고하는 바이다.

\section{증 례}

\section{1. 임상소견}

42세 남자가 과거에 B형간염을 진단 받았으나 추적 관찰 없이 지내던 중 타 병원에서 시행한 검진 복부초음파 검사 에서 간 종양이 발견되어 내원하였다. 29세 때 충수절제술 을 시행 받은 병력이 있었으며 가족력은 없었고 10 갑년의 흡연력 및 주 3 회, 회당 소주 1 병의 음주력이 있었다. 문진 소견에서 경미한 우상복부 불편감 및 1 년간 $5 \mathrm{~kg}$ 의 체중 감 소가 있었다. 이학적 검사에서 공막의 황달, 우상복부의 압 통은 없었고, 간이나 비장은 촉지되지 않았다. 내원 당시 시 행한 혈액검사는 백혈구 $4,280 / \mu \mathrm{L}$, 혈색소 $14.6 \mathrm{~g} / \mathrm{dL}$, 혈소판 $83,000 / \mu \mathrm{L}$, 총 단백 $7.9 \mathrm{~g} / \mathrm{dL}$, 알부민 $3.9 \mathrm{~g} / \mathrm{dL}$, 아스파르테이 트아미노전이효소 $71 \mathrm{IU} / \mathrm{L}$, 알라닌아미노전이효소 $65 \mathrm{IU} / \mathrm{L}$, 총 빌리루빈 $1.8 \mathrm{mg} / \mathrm{dL}$, 알칼리인산분해효소 $104 \mathrm{IU} / \mathrm{L}$, 감 마글루타밀트랜스펩티다아제 $50 \mathrm{IU} / \mathrm{L}$, 프로트롬빈 시간 1.18 국제정상화비율이었다. 바이러스 간염 표지자 검사는 $\mathrm{B}$ 형간염 표면항원 양성, B형간염 핵항원 음성, B형간염 핵 항체 양성이었으며 C형간염 항체는 음성이었다. B형간염 혈중 바이러스 농도는 $258 \mathrm{IU} / \mathrm{mL}$ 였으며 알파태아단백은 $108,436.5 \mathrm{ng} / \mathrm{mL}$, protein induced by vitamin $\mathrm{K}$ absence or antagonist (PIVKA)-II는 $331 \mathrm{mAU} / \mathrm{mL}$ 로 측정되었다.

\section{2. 영상소견}

간 자기공명영상에서 간 우엽의 대부분을 차지하는 약 10 $\mathrm{cm}$ 크기의 종양 및 인접부위의 간문맥 침윤이 관찰되었다. 우간문맥 첫 번째 분지까지 간문맥 침윤이 있었으며 간외문
맥간 침윤은 없었다. 종양은 동맥기 조영증강 및 지연기 조 영감소를 보여, 임상적 진단 기준 ${ }^{5}$ 에 의거하여 간세포암종 으로 진단하였다(Fig. 1). 복부 내 다른 부위의 전이는 없었 으며 흥부 전산화 단층 촬영 및 양전자 방출 단층 촬영상 추 가 전이 소견은 없었다.

\section{3. 진단 및 치료경과}

환자는 만성 $\mathrm{B}$ 형간염으로 인한 간세포암종(American Joint Committee on Cancer [AJCC] stage IIIB [cT3bNOM0], modified International Union Against Cancer [mUICC] stage III [T3N0M0], Barcelona Clinic Liver Cancer [BCLC] stage C)으로 진단하였으며 Child-Pugh A등급이나 종양의 크기 가 크고 간문맥 침윤이 동반되어 근치적 절제나 간이식은 불가능한 상태였다. 먼저 Yttrium-90 (TheraSphere ${ }^{\circledR}, \mathrm{BTG}$, London, England)을 사용한 방사선색전술을 시행하였으며 지속 추적 결과 종양 감축 효과를 보이다 방사선색전술 6 개 월 뒤부터 종양 크기가 다시 증가하는 모습을 보여 종양 혈 관을 초선택하여 간동맥 화학요법을 시행하고 동시에 간문 맥 혈전 부위에 총 $100 \mathrm{~Gy}$ (회당 $4 \mathrm{~Gy}$ )의 정위체부방사선치 료를 시행하였다. 간동맥 화학요법은 cisplatin $\left(60 \mathrm{mg} / \mathrm{m}^{2}\right.$, D2)과 5-fluorouracil (500 mg/m², D1, D2, D3)을 1달 간격으 로 총 6회 주입하였다.

추적 관찰로 시행한 복부 전산화 단층 촬영 결과 우측 종 양의 크기가 $3.9 \mathrm{~cm}$ 로 감소하고 간문맥 혈전이 소실되어 (Fig. 2) Milan 기준 내로 down-staging이 되었다. 혈액 검사 는 총 단백 $5.2 \mathrm{~g} / \mathrm{dL}$, 알부민 $2.4 \mathrm{~g} / \mathrm{dL}$, 아스파르테이트아미 노전이효소 $28 \mathrm{IU} / \mathrm{L}$, 알라닌아미노전이효소 $20 \mathrm{IU} / \mathrm{L}$, 총 빌 리루빈 $5.5 \mathrm{mg} / \mathrm{dL}$, 알칼리인산분해효소 $132 \mathrm{IU} / \mathrm{L}$, 감마글루 타밀트랜스펩티다아제 $35 \mathrm{IU} / \mathrm{L}$, 프로트롬빈 시간 1.41 국제 정상화비율이었으며 알파태아단백은 $99.77 \mathrm{ng} / \mathrm{mL}$, protein
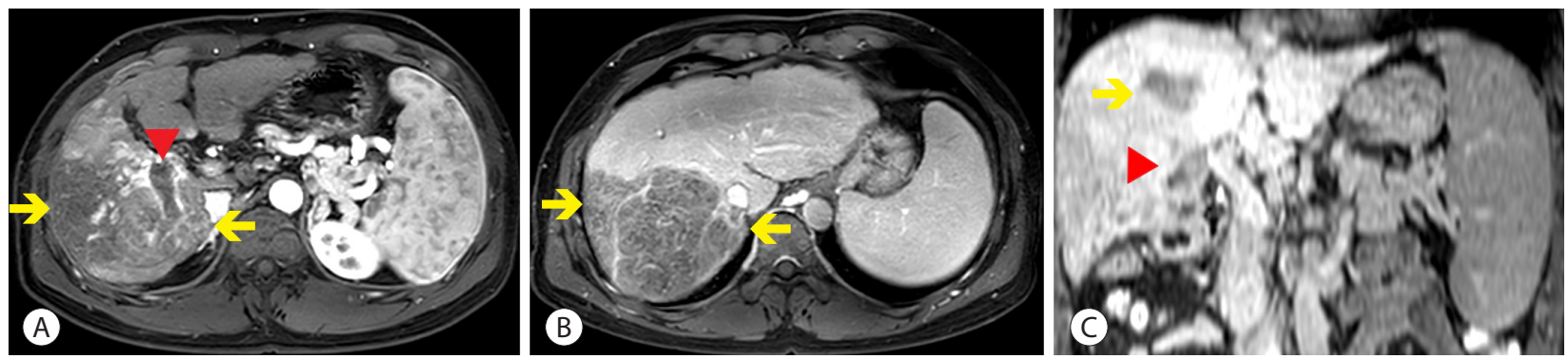

Figure 1. About $10 \mathrm{~cm}$ hepatocellular carcinoma at Rt. lobe of the liver (yellow arrows). Portal vein thrombosis was also found (red arrowhead). (A) MRI (arterial phase, axial view), (B) MRI (delayed phase, axial view), (C) MRI (arterial phase, coronal view). MRI, magnetic resonance imaging. 

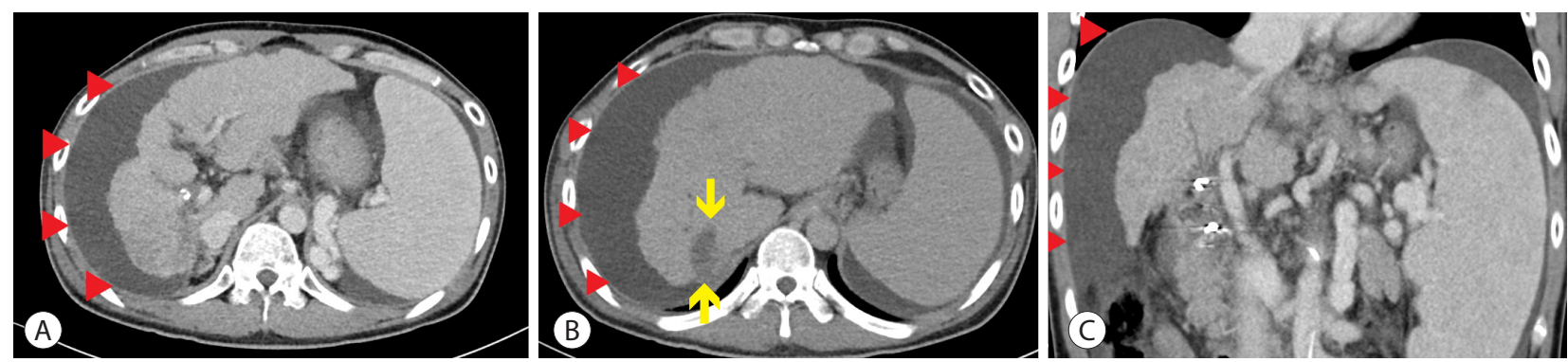

Figure 2. CT scan after treated with radioembolization, transarterial chemoinfusion, and stereotactic body radiation therapy. The main mass was greatly reduced (yellow arrows), and portal vein thrombosis was in obliterated status. Ascites was also found (red arrowheads). Coiling material and hepatic artery port catheter were seen as artifacts. (A) CT (arterial phase, axial view), (B) CT (delayed phase, axial view), (C) CT (arterial phase, coronal view). CT, computed tomography.
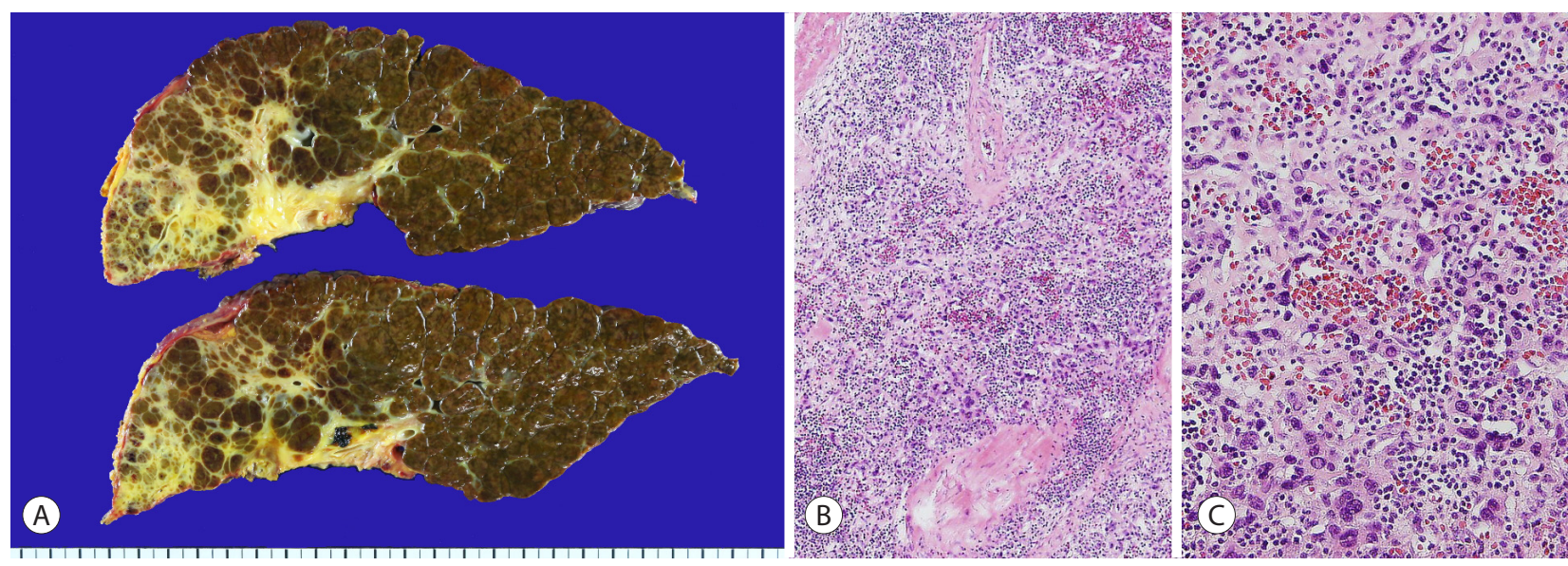

Figure 3. Pathological findings. (A) Gross examination of resected liver. (B) Photomicrographs of HCC lesion (Hematoxylin and eosin [H\&E] stain $\mathrm{X}$ 40). (C) Photomicrographs of HCC lesion (H\&E stain $\times 100)$. HCC, hepatocellular carcinoma.

induced by vitamin $\mathrm{K}$ absence or antagonist (PIVKA)-II는 52 $\mathrm{mAU} / \mathrm{mL}$ 로 감소하였다. 간기능 지표의 악화 및 조절되지 않는 복수로 환자는 Child Pugh C 등급에 해당하였으며 적 극적인 치료에도 불구하고 복수가 조절되지 않고 점차 악 화되는 양상을 보여 생체간이식을 시행하였다.

제거된 환자의 간은 전체적으로 간경변증 소견을 보였으 며 우측 간에 $6.9 \times 4.3 \times 3 \mathrm{~cm}$ 크기의 종양이 관찰되었다 (Fig. 3A). 이전 치료로 인하여 종양의 $95 \%$ 부위에서 괴사와 섬유화 변화를 보였고 남은 생존 종양은 $0.5 \times 0.2 \times 0.1 \mathrm{~cm}$ 크기로 관찰되었다. 병리학적으로 생존 종양의 세포는 육 주형으로 섬유화 변화 및 림프형질세포 침윤이 관찰되었으 며 Edmondson-Steiner 3 등급 분화를 보였고 혈관 및 담도 침윤 소견은 없었다(Fig. $3 \mathrm{~B}, \mathrm{C}$ ). 우간문맥에서 혈전이 관찰 되었으나 종양 세포는 관찰되지 않았다. 현재 환자는 이식 후 3 개월이 경과하였으며 재발 없이 추적 관찰 중이다.

\section{고 찰}

Milan 기준을 벗어난 진행성 간세포암종에서 down-staging을 통한 간이식은 간세포암종 및 기저 간질환을 치료할 수 있는 이상적인 치료법이다. 진행된 간세포암종의 성공적 인 down-staging 이후 시행한 간이식은 1년 생존율 $87.5 \%, 4$ 년 생존율 $69.3 \%$ 의 좋은 성적을 보였다. ${ }^{6}$ 다만, 이상적인 downstaging을 위한 기준은 아직까지 정립된 바 없으며 downstaging의 성공률을 올리기 위하여 대상 기준의 설정, 성공적 인 down-staging의 정의, down-staging과 간이식 사이의 간격 과 down-staging의 방법에 대한 논의가 이루어져야 한다. Down-staging 후 무분별한 간이식은 오히려 나쁜 예후를 보 이므로 ${ }^{8}$ 영상학적 정보를 토대로 한 종양의 크기와 분포, 침 범 정도의 확인뿐만 아니라 생물학적 표지자(알파태아단 백), ${ }^{9}$ 전구 세포 표지자(사이토케라틴 19$)^{10}$ 같은 다방면의 분 
석을 통하여 적절한 대상을 선별하고 시간 간격을 고려한 성 공적인 down-staging을 확인 후 간이식을 진행하여야 한다. 다양한 치료방법 중 down-staging의 방법으로 우월한 치료 는 없으나 단독치료보다는 병용치료가 좋은 성적을 보였다. ${ }^{4}$ 일반적으로 간문맥 침윤이 동반되어 진행된 간세포암종 은 간이식의 금기로 알려져 있지만 ${ }^{11}$ 한 연구에서 동시항암 방사선치료 및 간동맥 항암치료를 통하여 down-staging 후 성공적인 생체간이식을 진행 후 33 개월의 중간 생존기간을 확인하였다. ${ }^{12}$

본 증례의 경우 종양의 크기가 크고 체적이 전체 간부피 의 $60 \%$ 이상을 차지하여 전체 종양에 $30 \mathrm{~Gy}$ 이상의 방사선 치료를 시행할 경우 방사선 유발 간독성이 예상되는 바 ${ }^{13}$ 간 독성을 최소화하기 위하여 방사선색전술을 시행하였다. 이 후 진행 양상이 확인되어 간동맥 화학요법 치료와 동반된 간문맥 혈전 부위에 정위체부방사선치료를 병용하여 Milan 기준 내로 down-staging을 이룬 후 생체간이식을 시행할 수 있었다. 아직 명확한 기준이 설립되어 있지 않지만 Milan 기 준을 만족하지 않는 진행성 간세포암종에서 down-staging 을 통하여 완치를 위한 간이식을 적극적으로 고려해야 하겠 다. 또한 down-staging 후 간이식을 받은 환자에서 간세포암 종의 재발이 $16 \%$ 로 흔하므로 ${ }^{4}$ 주의 깊은 추적관찰이 이루 어져야 한다.

\section{AUTHOR CONTRIBUTIONS}

Yeong Jin Kim: Drafting the article, analysis and interpretation of data, final approval of the version to be published.

Yeon Seung Chung: Analysis and interpretation of data, final approval of the version to be published.

Beom Kyung Kim: Revising the article critically for important intellectual content, final approval of the version to be published.

Jin Sil Sung: Analysis and interpretation of data, final approval of the version to be published.

Do Young Kim: Substantial contributions to conception, revising the article critically for important intellectual content, final approval of the version to be published.

\section{Conflicts of Interest}

The authors have no conflicts to disclose.

\section{REFERENCES}

1. O'Grady JG, Polson RJ, Rolles K, Calne RY, Williams R. Liver transplantation for malignant disease. Results in 93 consecutive patients. Ann Surg 1988;207:373-379.

2. Mazzaferro V, Regalia E, Doci R, Andreola S, Pulvirenti A, Bozzetti F, et al. Liver transplantation for the treatment of small hepatocellular carcinomas in patients with cirrhosis. N Engl J Med 1996;334:693-699.

3. Cheng AL, Kang YK, Chen Z, Tsao CJ, Qin S, Kim JS, et al. Efficacy and safety of sorafenib in patients in the Asia-Pacific region with advanced hepatocellular carcinoma: a phase III randomised, doubleblind, placebo-controlled trial. Lancet Oncol 2009;10:25-34.

4. Parikh ND, Waljee AK, Singal AG. Downstaging hepatocellular carcinoma: a systematic review and pooled analysis. Liver Transpl 2015;21:1142-1152.

5. European Association For The Study Of The Liver; European Organisation For Research And Treatment Of Cancer. EASL-EORTC clinical practice guidelines: management of hepatocellular carcinoma. J Hepatol 2012;56:908-943.

6. Yao FY, Kerlan RK Jr, Hirose R, Davern TJ 3rd, Bass NM, Feng S, et al. Excellent outcome following down-staging of hepatocellular carcinoma prior to liver transplantation: an intention-to-treat analysis. Hepatology 2008:48:819-827.

7. Toso C, Mentha G, Kneteman NM, Majno P. The place of downstaging for hepatocellular carcinoma. J Hepatol 2010;52:930-936.

8. Axelrod D, Koffron A, Kulik L, Al-Saden P, Mulcahy M, Baker T, et al. Living donor liver transplant for malignancy. Transplantation 2005;79:363-366.

9. Toso C, Asthana S, Bigam DL, Shapiro AM, Kneteman NM. Reassessing selection criteria prior to liver transplantation for hepatocellular carcinoma utilizing the Scientific Registry of Transplant Recipients database. Hepatology 2009;49:832-838.

10. Miltiadous $O$, Sia D, Hoshida Y, Fiel MI, Harrington AN, Thung SN, et al. Progenitor cell markers predict outcome of patients with hepatocellular carcinoma beyond Milan criteria undergoing liver transplantation. J Hepatol 2015;63:1368-1377.

11. Choi HJ, Kim DG, Na GH, Hong TH, You YK. Extended criteria for living donor liver transplantation in patients with advanced hepatocellular carcinoma. Transplant Proc 2012;44:399-402.

12. Han DH, Joo DJ, Kim MS, Choi GH, Choi JS, Park YN, et al. Living donor liver transplantation for advanced hepatocellular carcinoma with portal vein tumor thrombosis after concurrent chemoradiation therapy. Yonsei Med J 2016;57:1276-1281.

13. Kim TH, Kim DY, Park JW, Kim SH, Choi Jl, Kim HB, et al. Dosevolumetric parameters predicting radiation-induced hepatic toxicity in unresectable hepatocellular carcinoma patients treated with threedimensional conformal radiotherapy. Int J Radiat Oncol Biol Phys 2007;67:225-231. 